\title{
The Use of Nominal Phrases in Terminology of Covid-19 in Online Media (Syntax Study)
}

\author{
Nabila Auliya*, Kusnul Khatimah, Sumarlam \\ Pascasarjana, Universitas Sebelas Maret, Indonesia \\ nabeellia@gmail.com*, kusnulkhotim@gmail.com,sumarlam@staff.uns.ac.id
}

DOI: $10.20884 / 1 . j 1 i .2020 .11 .2 .2630$

\begin{abstract}
Article History: ABSTRACT
First Received: $\quad$ This study aims to describe the use of noun phrase in from the terms of

$24 / 4 / 2020$ COVID-19 in CNNIndonesia.com online news. The object of this research is the nominal phrase found in the terms of COVID-19 in the

Final Revision: CNN Indonesia.com online news. The data source of this research is 8 $16 / 5 / 2020$ news articles that has been uploaded by CNNIndonesia.com online news from 26 to 27 march 2020. The method used in the provision of data is the observing method by using taking note technique. The method used

Available online: in analyzing the data is the distributional method. The results of this

29/12/2020 research revealed that there were 27 nominal phrases used in 8 news articles that has been uploaded by CNNIndonesia.com online news from 26 to 27 March 2020.
\end{abstract}

Keywords: nominal phrase; news; Covid-19

\section{PENDAHULUAN}

Lingustik merupakan ilmu pengetahuan yang objek kajianya adalah bahasa. Bahasa merupakan alat komunikasi yang efektif untuk menyampaikan ide, pesan, maksud, perasaan, serta pendapat kepada orang lain. Maka bahasa digunakan untuk berkomunikasi, bertukar pikiran, ataupun mengutarakan pendapat yang ingin disampaikan dari satu orang ke orang yang lain. Sebagai sarana komunikasi, bentuk bahasa dapat dibagi menjadi dua yaitu bahasa lisan dan bahasa tulis. Adapun beberapa contoh bahasa lisan yaitu pidato, ceramah, diskusi, ataupun percakapan. Sedangkan contoh bahasa tulisan adalah buku, karya ilmiah, tabloid, artikel, poster, iklan, majalah, dan surat kabar ataupun berita. Di era ini, baik bahasa lisan ataupun tulisan dapat diakses secara daring atau online melalui gadget, sehingga bahasa lisan tidak selalu harus didengar dari 
sumbernya secara langsung, dan bahasa tulisan tidak selalu berbentuk cetak, tak terkecuali surat kabar. Sekarang ini surat kabar dapat diakses melalui daring atau secara online.

Surat kabar merupakan salah satu media bahasa tulisan yang sangat dekat dengan kehidupan sehari-hari. Biasanya berisi mengenai informasi kejadian-kejadian yang sedang hangat dibicarakan. Menurut Kamus Besar Bahasa Indonesia Edisi V tahun 2016, berita merupakan cerita atau keterangan mengenai kejadian atau peristiwa yang hangat, kabar; laporan; pemberitahuan, pengumuman. Sumadiria (2005) berpendapat bahwa berita merupakan laporan tercepat mengenai ide atau fakta terbaru yang benar, menarik, dan penting bagi sebagian besar khalayak, melalui media berkala seperti surat kabar, radio, televisi, atau media internet.

Terdapat beberapa jenis berita dalam surat kabar. Jenis berita ini terbagi menjadi 2 yaitu hard news dan soft news. Hard news adalah berita yang isinya memiliki nilai lebih, beritanya berkualitas dan terbaru. Isi beritanya sangat penting, sehingga harus segera disampaikan kepada masyarakat. Biasanya isi berita hard news adalah berita yang berisi tentang suatu kejadian yang terjadi secara tiba-tiba, sedangkan soft news merupakan berita pendukung dan mempunyai nilai berita di bawah hard news. Di samping itu, terdapat pula jenis berita yang disebut dengan depth news atau berita mendalam. Berita jenis ini mempunyai isi yang bersifat mendalam yang isinya yang lebih menonjolkan tentang "mengapa peristiwa itu terjadi" dan juga "bagaimana peristiwa itu terjadi". Sedangkan investigation news atau berita investigasi yang bertujuan untuk mengungkap hal-hal yang tersembunyi dari sebuah kejadian. Terdapat pula jenis berita interpretative news yang merupakan berita langsung yang di dalamnya ditambahkan beberapa informasi seperti pendapat seseorang atau sebuah penelitian yang dilakukan oleh penulis. Opinion news berisi opini tentang suatu kejadian yang sedang terjadi. Biasanya isinya adalah pendapat dari para pengamat atau para ahli dari masalah, isu, atau dari kejadian yang sedang terjadi. Di era ini, surat kabar online (online news) menjadi pilihan bagi mayoritas orang, terlebih untuk yang memiliki mobilitas yang tinggi. Hal ini disebabkan surat kabar online mudah diakses di mana saja dan fleksibel.

Berita online mulai eksis sekitar pertengahan tahun 1990-an dengan berkembangnya internet dan website. Berita online pertama kali muncul pada awal 1980-an, yaitu pada tahun 1983 grup koran Knight-Ridder dan AT\&T meluncurkan revolusi eksperimennya untuk membawa orang-orang menjelajahi informasi lewat komputer mereka sendiri. Berita ini disebarkkan secara online dalam bentuk teks, audio, video, dan live streaming. Menurut Salwen (2005), jurnalistik masa depan ditemukan di internet dan suatu hari online news akan menjadi jurnalistik utama karena World Wide Web dibuktikan dapat mentransformasikan kebudayaan, bahasa, dan 
informasi. Perkembangan pesat dari online news ini disinyalir karena menawarkan isi (content), teknologi (technologies), dan distribusi (distribution).

Berita online adalah tahap penting bagi konvergensi media. Berita online berpotensi memanfaatkan berbagai fitur baru dari dunia pencampuran komunikasi media digital, di antaranya audio, video, animasi, dan peningkatan kontrol pengguna. Kelebihan dari online news ini adalah kemudahan dalam pembaruan berita secara berkelanjutan (continuous updates), memiliki interaktivitas, hypertext, serta multimedia. Di samping itu, tampilan berita online jauh lebih menarik jika dibandingkan dengan surat kabar cetak karena memadukan teks, audio, video, serta visual. Sehingga, tidak perlu lagi membeli media massa cetak hanya untuk mengetahui kejadiankejadian terkini yang terjadi di dalam negeri maupun mancanegara. Salah satu portal berita online yang ada di Indonesia adalah $\underline{w w w . c n n i n d o n e s i a . c o m}$.

CNN (Cable News Network Indonesia) merupakan suatu saluran televisi dan situs milik Trans Media. CNN diluncurkan pertama kali pada tanggal 15 Desember 2015 saat Trans Media memperingati ulang tahun yang ke-14. Saluran televisi dan situs ini memberitakan berbagai hal seperti bisnis, olahraga, teknologi, dan hiburan, baik yang terjadi dalam negeri maupun mancanegara. Salah satu hal yang kini sedang marak diberitakan oleh CNN adalah pandemi COVID-19 yang saat ini sedang meresahkan dunia.

Menurut Organisasi Kesehatan Dunia atau WHO (World Health Organization), istilah pandemi berarti wabah penyakit yang terjadi pada geografis yang luas dan menyebar secara global atau mendunia, sedangkan COVID-19 merupakan singkatan dari Corona Virus Disease 2019 yang berarti penyakit virus corona 2019. Corona Virus Disease merupakan nama resmi penyakit yang disebabkan oleh virus corona SARS-Cov-2 (Severe Acute Respiratory Syndrome Coronavirus 2) yang berarti jenis virus dari keluarga virus corona yang menyebabkan seseorang terkena penyakit COVID-19 (Corona Virus Disease 2019). Saat ini, pandemi ini sudah menyebar ke 189 negara dan terus memakan korba

Hingga hari ini, pemberitaan mengenai pandemi COVID-19 masih berlangsung. Munculnya kosakata, istilah, dan frasa-frasa unik yang asing di telinga kita merupakan hal yang menarik untuk diteliti, salah satunya dari segi sintaksis. Pada hakikatnya, kata sintaksis berasal dari bahasa Yunani, yaitu sun yang berarti "dengan" dan kata tattein yang berarti "menempatkan". Sehingga, sintaksis dapat diartikan menempatkan kata secara bersama-sama menjadi kelompok kata atau kalimat. Menurut Manaf (2009), sintaksis adalah cabang linguistik yang membahas struktur 
internal kalimat. Struktur internal kalimat yang dibahas adalah frasa, klausa, dan kalimat. Chaer (2009) berpendapat bahwa subsistem sintaksis membicarakan penataan dan pengaturan kata-kata ke dalam satuan-satuan yang lebih besar. Satuan-satuan tersebut disebut dengan sintaksis, yakni kata, frasa, klausa, kalimat, dan wacana. Arifin (2009) menjelaskan bahwa pengertian sintaksis merupakan bidang subdisiplin linguistik yang mempelajari hubungan antar kata dalam tuturan yang meliputi tata susun frase, tata susun klausa, dan tata susun kalimat dalam suatu bahasa.

Penelitian mengenai frasa nominal telah dilakukan oleh beberapa peneliti sebelumnya. Yang pertama adalah Permana (2010) yang berjudul "Frasa Nominal dalam Bahasa Banjar Samarinda". Tujuan dari penelitian tersebut adalah mendeskripsikan frasa nominal dalam Bahasa Banjar Samarinda. Adapun hasil dari penelitian ini adalah disimpulkan bahwa frasa nominal yang terdapat di dalam bahasa Banjar Samarinda dapat berbentuk: (1) N/nomina (sebagai unsur inti) diikuti N/nomina (sebagai pewatasnya), (2) Frasa nominal dengan pewatas adjektiva, yaitu N/nomina (sebagai unsur inti) diikuti Adj./Adjektiva (sebagai pewatasnya), (3) Frasa nominal dengan pewatas verba, yaitu N/nomina (sebagai unsur inti) diikuti V/verba (sebagai pewatasnya), (4). Frasa nominal dengan pewatas numeralia, yaitu N/nomina (sebagai unsur inti) diikuti Num./numeralia (sebagai pewatasnya), (5) Frasa nominal dengan pewatas adverbial, yaitu N/nomina (sebagai unsure inti) diikuti Adv./adverbial (sebagai pewatasnya), (6) Frasa nominal dengan pewatas frasa posposisional, yaitu N/nomina (sebagai unsur inti) diikuti F pos./Frasa posposisional (sebagai pewatasnya), dan (7) Frasa nominal dengan pewatas pronominal (kata ganti penunjuk), yaitu N/nomina (sebagai unsur inti) diikuti Pron./pronominal/kata ganti penunjuk (sebagai pewatasnya).

Penelitian selanjutnya adalah Rahman (2012) dengan penelitianya yang berjudul "Penggunaan Frasa Bahasa Indonesia dalam Karangan Siswa Kelas VII MTSn Rengel Tahun Pelajaran 2014/2015”. Sesuai dengan judulnya, penelitian ini bertujuan untuk (1) mendiskripsikan bentuk nomina yang menjadi unsur inti, (2) jenis kata yang menjadi unsur atribut, (3) pola, dan (4) unsur fungsi yang diduduki frasa nominal bahasa Indonesia dalam karangan. Hasil penelitian ini menunjukkan bahwa: (1) terdapat dua bentuk nomina yang menjadi unsur inti frasa nominal: nomina bentuk dasar dan nomina bentuk turunan; (2) Jenis kata yang menjadi unsur atribut pada frasa nomona bahasa Indonesia terdiri atas lima macam: (a) kata benda, (b) kata kerja, (c) kata sifat, (d) kata bilangan, dan (e) kata ganti; (3) Pola frasa nominal bahasa Indonesia meliputi dua hal: (a) pola DM dan (b) pola MD; dan (4) unsur fungsi yang diduduki frasa nominal bahasa Indonesia terdiri atas empat fungsi: (a) subjek, (b) predikat, (c) objek, dan (d) pelengkap. 
Penelitian selanjutnya adalah Jeniati (2013) dengan penelitianya yang berjudul "Posisi Pewatas dalam Frasa Nomina Bahasa Mandar: Suatu Pendekatan Transformasi Generatif". Sesuai dengan judulnya, penelitian ini bertujuan untuk mendeskripsikan posisi pewatas yang menjadi pemarkah frasa Bahasa Mandar. Hasil penelitian ini menunjukkan bahwa terdapat dua posisi pewatas yang terdapat dalam frasa nominal Bahasa Mandar, yaitu posisi pewatas mendahului inti, dan posisi inti mendahului pewatas. Frasa nomina bahasa Mandar dapat terbentuk dari nomina selaku inti frasa dibatasi oleh berbagai pemarkah, seperti nomina, pronomina posesif, numeralia, adjektiva, demonstratif, artikel, kata tanya, dan klausa relatif.

Penelitian selanjutnya adalah Afandi (2018) dengan penelitianya yang berjudul "Analisis Penggunaan Frasa Nomina dari Segi Sintaksis dalam Teks Akademik".Sesuai dengan judulnya, penelitian bertujuan untuk mendeskripsikan penggunaan frasa nomina dari segi sintaksisnya pada bagian latar belakang tesis. Hasil penelitian ini menunjukkan bahwa terdapat frasa nominal dengan pewatas numeralia, pewatas nomina, pewatas verba, pewatas adjektiva, pewatas determinan, frasa preposisional, dengan total penggunaan frasa nomina sebanyak 27 frasa nominal.

Penelitian selanjutnya adalah Dongalemba (2018) dengan penlitianya yang berjudul "Fungsi Eksternal dan Kategori Frasa Nomina Bahasa Melayu Menado". Sesuai dengan judulnya, tujuan dari penelitian ini adalah mendeskrisipkan fungsi eksternal dan kategori frasa nomina dalam bahasa melayu manado. Hasil penelitian ini menunjukkan bahwa menemukan 18 data kalimat dalam bahasa Melayu Manado. Tataran fungsi eksternal sintaksis diisi oleh subjek, predikat, dan adverbia. Tataran kategori eksternal, frase nominal melekat pada fungsi subjek yaitu sebanyak 13 klausa, frase nomina yang melekap pada fungsi predikat yaitu sebanyak 11 klausa, dan frase nomina yang melekat. pada adverbia yaitu sebanyak 6 klausa.

Penelitian ini memiliki persaman dengan beberapa penelitian yang pernah dilakukan sebelumnya, yaitu mengkaji penggunaan frasa nominal. Adapun perbedaanya adalah jika penelitian sebelumnya mengkaji bentuk nomina yang menjadi unsur inti, jenis kata yang menjadi unsur atribut, pola, unsur fungsi, ataupun hanya mengkaji pewatas yang menjadi pemarkah frasa nominal, penelitian ini hanya mengkaji bentuk frasa nonimal yang berupa nomina sebagai unsure intinya serta jenis kata yang menjadi atribut atau pewatasnya yang muncul pada artikel peristilahan COVID-19 pada media online CNN.Indonesia.com. 


\section{Frasa}

Menurut Tarmini (2012), Frasa adalah suatu konstruksi yang terdiri atas dua konstituen atau lebih yang dapat mengisi fungsi sintaksis tertentu dalam kalimat tetapi tidak melampaui batas fungsi klausa atau dapat dikatakan frasa itu nonpredikatif. Frasa merupakan kelompok kata yang menduduki suatu fungsi dan kesatuan makna dalam kalimat (Faisal, 2009). Frasa lazim didefinisikan sebagai satuan gramatikal yang berupa gabungan kata yang bersifat nonpredikatif, atau lazim juga disebut gabungan kata yang mengisi salah satu fungsi sintaksis di dalam kalimat. Frasa tidak memiliki makna baru, melainkan makna sintaktik atau makna gramatikal.

Dalam bahasa Indonesia terdapat konstruksi frasa yang biasanya disebut dengan istilah kelompok kata karena bentuk kontruksi tersebut terdiri atas dua atau lebih sebagai anggotanya dan hubungan antara unsur langsungnya bersifat longgar atau terbuka. Frasa ditinjau dari segi persamaan distribusi dengan golongan atau kategori kata, terdiri atas frasa nominal, frasa verbal, frasa ajektival, frasa pronominal, dan frasa numerelia (Depdikbud dalam Faisal, 2009).

\section{Frasa Nominal}

Berdasarkan kategorinya, frasa dibagi menjadi frasa verbal, frasa adjektiva, frasa adverbia, frasa prepopsional, ataupun frasa nominal. Frasa nominal adalah frasa modifikatif yang terdiri dari nomina sebagai induk dan unsur perluasan lain yang mempunyai hubungan subordinatif dengan induk yaitu adjektiva, verba, numeralia, demonstratif, pronominal, artikula, frasa preposisi, frasa dengan artikula, frasa preposisi, atau frasa lain

Menurut Widjono (2008), frasa nominal adalah kelompok kata benda yang dibentuk dengan memperluas sebuah kata benda ke kiri dan ke kanan; ke kiri berfungsi untuk menggolongkan, misalnya: dua buah buku, seorang teman, beberapa butir telur; dan ke kanan sesudah kata benda (inti) berfungsi mewatasi (membatasi), misal: buku dua buah, teman seorang, telur beberapa butir. Widjono (2008) juga menggolongkan frasa nominal menjadi 3 jenis yaitu: (1) Frasa nominal modifikatif (mewatasi), misalnya: rumah mungil, hari Minggu, buku dua buah, dan pemuda kampus; (2) Frasa nominal koordinatif (tidak saling menerangkan), misalnya: sandang pangan, dunia akhirat, lahir batin, serta adil makmur; dan (3) Frasa nominal apositif, misalnya : Toni, Supir taksi itu.

\section{METODE PENELITIAN}

Penelitian ini merupakan penelitian deskriptif dengan menggunakan pendekatan kualitatif. Sugiono (2009) menjelaskan bahwa metode deskriptif merupakan metode yang berfungsi untuk 
mendeskripsikan atau memberi gambaran terhadap objek yang diteliti melalui data atau sampel yang telah terkumpul sebagaimana adanya tanpa melakukan analisis dan membuat kesimpulan yang berlaku untuk umum, kemudian menganalisis serta menginterpertasikan ke dalam bentuk narasi. Penelitian ini merupakan studi kasus terpancang yang merupakan studi kasus bahasa dikarenakan peneliti telah menentukan fokus dari penelitian dan pokok masalah yang akan diteliti. Fokus dalam penelitian ini adalah frasa nominal yang digunakan pada peristilahan COVID-19 dalam media online CNN. Indonesia (https://www.cnnindonesia.com/). Dalam penelitian ini, peneliti mengklasifikasikan dan mendeskripsikan frasa nominal yang digunakan pada peristilahan COVID-19 pada media online ke dalam bentuk kata-kata dan bahasa, sehingga peneliti memaparkan gambaran mengenai yang diteliti dalam bentuk uraian naratif.

Dalam penelitian ini, analisis data dilakukan secara induktif. Spradley (1980) menjelaskan bahwa analisis induktif merupakan analisis data dilakukan dengan mengelompokkan data yang telah dikumpulkan dan diobservasi dalam kategori-kategori yang ada kemudian menyajikan kategori-kategori tersebut. Adapun posisi peneliti dalam penelitian merupakan instrumen utama dengan tujuan agar dapat memperoleh banyak data dan informasi untuk hasil peneliti yang lebih mendalam. Sugiono (2009) menjelaskan bahwa Peneliti kualitatif sebagai human instrumen berfungsi menetapkan fokus penelitian, memilih informan sebagai sumber data, melakukan pengumpulan data, menilai kualitas data, analisis data, menafsirkan data dan membuat kesimpulan atas temuannya.

Data dalam penelitian ini merupakan data linguistik atau data kebahasaan yang berupa frasafrasa nominal yang terkait dengan istilah-istilah COVID-19 yang ditemukan pada peristilahan COVID19 di media online CNN. Adapun sumber data dari penelitian ini merupakan sumber data dokumen yang diambil dari 8 berita tulis pada media online CNN. Hal ini sejalan dengan Santosa (2014) berpendapat bahwa sumber data dapat berbentuk dokumen, tempat, partisipan, kejadian, dan benda.

Adapun 8 judul berita yang menjadi sumber data dalam penelitian ini adalah: (1) PDP Corona Naik, RSMH Palembang Tambah Kapasitas Isolasi (Idz \& Haz, 2020), (2) Jawa Tengah Punya Laboratorium Pemeriksa COVID-19 (Dmr \& Antara/kid, 2020), (3) Stok Darah Berkurang saat Corona, PMI Jemput Bola Pendonor (Khr \& Kid, 2020), (4) Singapura Denda Warga yang Duduk Dekatan hingga Rp.100 Juta (Ang \& Dea, 2020), (5) Cegah Corona, Mahasiswa UNS Buat Ruang Penyemprot Disinfektan (Eks \& Eks, 2020), (6) Viral, Guru Besar FK UI Minta Jokowi 
Terapkan Local Lockdown (Dhf \& Arh, 2020), (7) Investor China Kirim 40 Ton Alat Kesehatan untuk Atasi Corona (Agt \& Bir, 2020), dan (8) Daftar Wilayah Transmisi Lokal Virus Corona di Indonesia (Psp \& Sur, 2020).

Pengumpulan data dalam penelitian ini dilakukan dengan menggunakan metode simak dengan teknik catat, yaitu penyimakan terhadap pemakaian bahasa terhadap 8 artikel berita tulis di media online CNN. Dalam penelitian ini, peneliti melakukan pengamatan terarah terhadap frasa-frasa nominal yang muncul terkait dengan peristilahan COVID-19 pada berita tulis di media online CNN serta memilah data-data lingual yang ada sehingga peneliti mengetahui mana yang merupakan data dalam penelitian ini ataupun yang bukan data. Adapun langka-langkah yang ditempuh oleh peneliti adalah: (1) Mengunduh artikel berita dari media online, (2) Menandai hal yang penting dalam artikel tersebut, terutama frasa- frasa nominal yang muncul terkait dengan COVID-19, (3) Menganalisis frasa-frasa nominal tersebut, serta (4) Mendeskripsikan hasil analisis dalam uraian naratif terhadap data yang telah didapatkan dan memberi label kode (coding) pada data. Adapun metode yang digunakan untuk menganalisis data adalah metode metode agih (distribusional) dengan teknik dasar bagi unsur langsung (BUL). Metode ini merupakan suatu metode yang memiliki alat penentu yang berasal dari bahasa yang diteliti. Adapun yan menjadi alat penentunya adalah bagian unsur dari objek yang diteliti seperti frasa, kata, ataupun klausa. Dalam penelitian ini, peneliti menganalisis penggunaan frasa nominal yang digunakan pada peristilahan COVID-19 dalam media online CNNIndonesia.com.

\section{HASIL DAN PEMBAHASAN}

Hasil penenelitian ini menunjukan bahwa terdapat 3 bentuk frasa nominal yang digunakan dalam peristilahan COVID-19 pada berita online CNN Indonesia, yaitu frasa nominal dengan pewatas nomina, frasa nominal dengan pewatas adjektiva, serta frasa nominal dengan pewatas verba. Adapun jumlah dari masing-masing frasa nominal tersebut adalah 11 data dengan 13 penggunaan frasa nominal dengan pewatas nomina, 12 data dengan 13 penggunaan frasa nominal dengan pewatas adjektiva, serta 1 data dengan penggunaan frasa nominal dengan pewatas verba. Adapun jumlah frasa nominal yang muncul dalam 8 artikel peristilahan COVID-19 tersebut adalah 27 frasa nominal.

Berikut adalah frasa-frasa nominal yang muncul pada peristilahan COVID-19 dalam media online CNN.Indonesia : 
Tabel 1. Frasa Nominal dengan Pewatas Nomina dan Adjektiva Pada Peristilahan COVID-19 dalam Media Online

\begin{tabular}{|c|c|c|c|c|c|}
\hline No. & $\begin{array}{c}\text { Nomor } \\
\text { data }\end{array}$ & Frasa & Sturktur Frasa & Definisi & Keterangan \\
\hline 1. & $\begin{array}{l}\text { FN/01/CNN } \\
\text { /Covid-19 }\end{array}$ & $\begin{array}{l}\text { transmisi } \\
\text { lokal }\end{array}$ & $\frac{\text { transmisi }}{\mathrm{N}} \frac{\text { lokal }}{\text { Adj. }}$ & $\begin{array}{l}\text { Penjangkitan } \\
\text { penyakit di satu } \\
\text { tempat } \\
\text { (Menunjukkan } \\
\text { Lokasi di mana } \\
\text { sumber infeksi } \\
\text { berada di dalam } \\
\text { lokasi pelaporan) }\end{array}$ & $\begin{array}{l}\text { FN dengan } \\
\text { pewatas } \\
\text { adjektiva }\end{array}$ \\
\hline 2. & $\begin{array}{l}\mathrm{FN} / 02 / \mathrm{CNN} \\
\text { /Covid-19 }\end{array}$ & virus corona & $\frac{\text { virus }}{\mathrm{N}} \frac{\text { corona }}{\mathrm{N}}$ & $\begin{array}{l}\text { Virus yang } \\
\text { menyebabkan } \\
\text { seseorng terkena } \\
\text { penyakit COVID- } \\
19 .\end{array}$ & $\begin{array}{c}\text { FN dengan } \\
\text { pewatas } \\
\text { nomina }\end{array}$ \\
\hline 3. & $\begin{array}{l}\text { FN/03/CNN } \\
\text { /Covid-19 }\end{array}$ & $\begin{array}{l}\text { positif } \\
\text { Covid-19 }\end{array}$ & $\frac{\text { positif }}{\text { Adj. }} \frac{\text { Covid-19 }}{\mathrm{N}}$ & $\begin{array}{l}\text { Status yang } \\
\text { menunjukkan } \\
\text { seseorang terkena } \\
\text { penyakit dari } \\
\text { virus Corona. }\end{array}$ & $\begin{array}{c}\text { FN dengan } \\
\text { pewatas } \\
\text { adjektiva }\end{array}$ \\
\hline 4. & $\begin{array}{l}\mathrm{FN} / 04 / \mathrm{CNN} \\
\text { /Covid-19 }\end{array}$ & $\begin{array}{l}\text { imported } \\
\text { case }\end{array}$ & $\frac{\text { imported }}{\mathrm{N}} \frac{\text { case }}{\mathrm{N}}$ & $\begin{array}{l}\text { Kasus yang } \\
\text { menunjukkan } \\
\text { pasien terinfeksi } \\
\text { penyakit di luar } \\
\text { area dinyatakan } \\
\text { terinfeksi (sudah } \\
\text { terkena wabah } \\
\text { atau penyakit } \\
\text { tersebut) }\end{array}$ & $\begin{array}{c}\text { FN dengan } \\
\text { pewatas } \\
\text { nomina }\end{array}$ \\
\hline 5. & $\begin{array}{l}\text { FN/05/CNN } \\
\text { /Covid-19 }\end{array}$ & rapid test & $\frac{\text { rapid }}{\text { Adj. }} \frac{\text { test }}{\mathrm{N}}$ & $\begin{array}{l}\text { teknologi } \\
\text { pengujian cepat } \\
\text { untuk virus } \\
\text { corona baru } \\
(\text { COVID-19) }\end{array}$ & $\begin{array}{c}\text { FN dengan } \\
\text { pewatas } \\
\text { adjektiva }\end{array}$ \\
\hline 6. & $\begin{array}{l}\mathrm{FN} / 06 / \mathrm{CNN} \\
\text { /Covid-19 }\end{array}$ & $\begin{array}{l}\text { kontak } \\
\text { dekat }\end{array}$ & $\frac{\text { kontak dekat }}{\mathrm{N}} \frac{\mathrm{Adj} .}{}$ & $\begin{array}{l}\text { Hubungan satu } \\
\text { dengan yang lain } \\
\text { dengan cara } \\
\text { saling berdekatan. }\end{array}$ & $\begin{array}{c}\text { FN dengan } \\
\text { pewatas } \\
\text { adjektiva }\end{array}$ \\
\hline 7. & $\begin{array}{l}\mathrm{FN} / 07 / \mathrm{CNN} \\
\text { /Covid-19 }\end{array}$ & $\begin{array}{l}\text { ruang } \\
\text { isolasi }\end{array}$ & $\frac{\text { ruang }}{\mathrm{N}} \frac{\text { isolasi }}{\mathrm{N}}$ & $\begin{array}{l}\text { Ruangan untuk } \\
\text { memisahkan } \\
\text { seorang dengan } \\
\text { orang yang lain } \\
\text { (diperuntukkan } \\
\text { untuk orang yang } \\
\text { membutuhkan }\end{array}$ & $\begin{array}{c}\text { FN dengan } \\
\text { pewatas } \\
\text { nomina }\end{array}$ \\
\hline
\end{tabular}




\section{FN/08/CNN kasus positif Kasus positif /Covid-19 \\ $\mathrm{N} \quad$ Adj.}

9. $\mathrm{FN} / 09 / \mathrm{CNN}$ /Covid-19

social distancing

social distancing

Adj. N

10. $\mathrm{FN} / 10 / \mathrm{CNN}$ masa /Covid-19 inkubasi

$\frac{\text { masa inkubasi }}{\mathrm{N}}$

11. FN/11/CNN jarak aman jarak aman /Covid-19 $\mathrm{N}$ Adj. penanganan

khusus)

Seseorang yang telah terbukti dan terkonfimasi positf mengidap Covid-19.

Gerakan untuk memberi jarak saat bertemu orang atau bermasyarakat (disebut jarak sosial)

Masa dari saat penyebab penyakit masuk ke dalam tubuh sampai ke waktu timbulnya suatu penyakit .

Gerakan memberi $\quad F N$ dengan jarak 1 meter ditempat umum untuk memutus rantai penularan suatu penyakit (virus).

Ruangan atau bilik pembasmian virus dengan menyemprotkan cairan disenfektan pada seluruh tubuh seseorang $\begin{array}{lll}\text { 13. } & \text { FN/13/CNN } & \text { kejadian } \\ \text { /Covid-19 } & \text { luar biasa } & \frac{\text { kejadian luar biasa }}{\mathrm{N}}\end{array}$

$\mathrm{N}$ Adj.
$\frac{\text { Karantina wilayah }}{\mathrm{N} \quad \mathrm{N}}$

FN dengan pewatas adjektiva

FN dengan pewatas adjektiva

FN dengan pewatas nomina pewatas adjektiva

FN dengan pewatas nomina

FN dengan pewatas adjektiva

FN dengan pewatas nomina
Status yang menggambarkan bahwa suatu daerah sedang terkena wabah atau musibah

Memencilkan atau membatasi gerakan seseorang dalam satu wilayah untuk memutus rantai penularan 


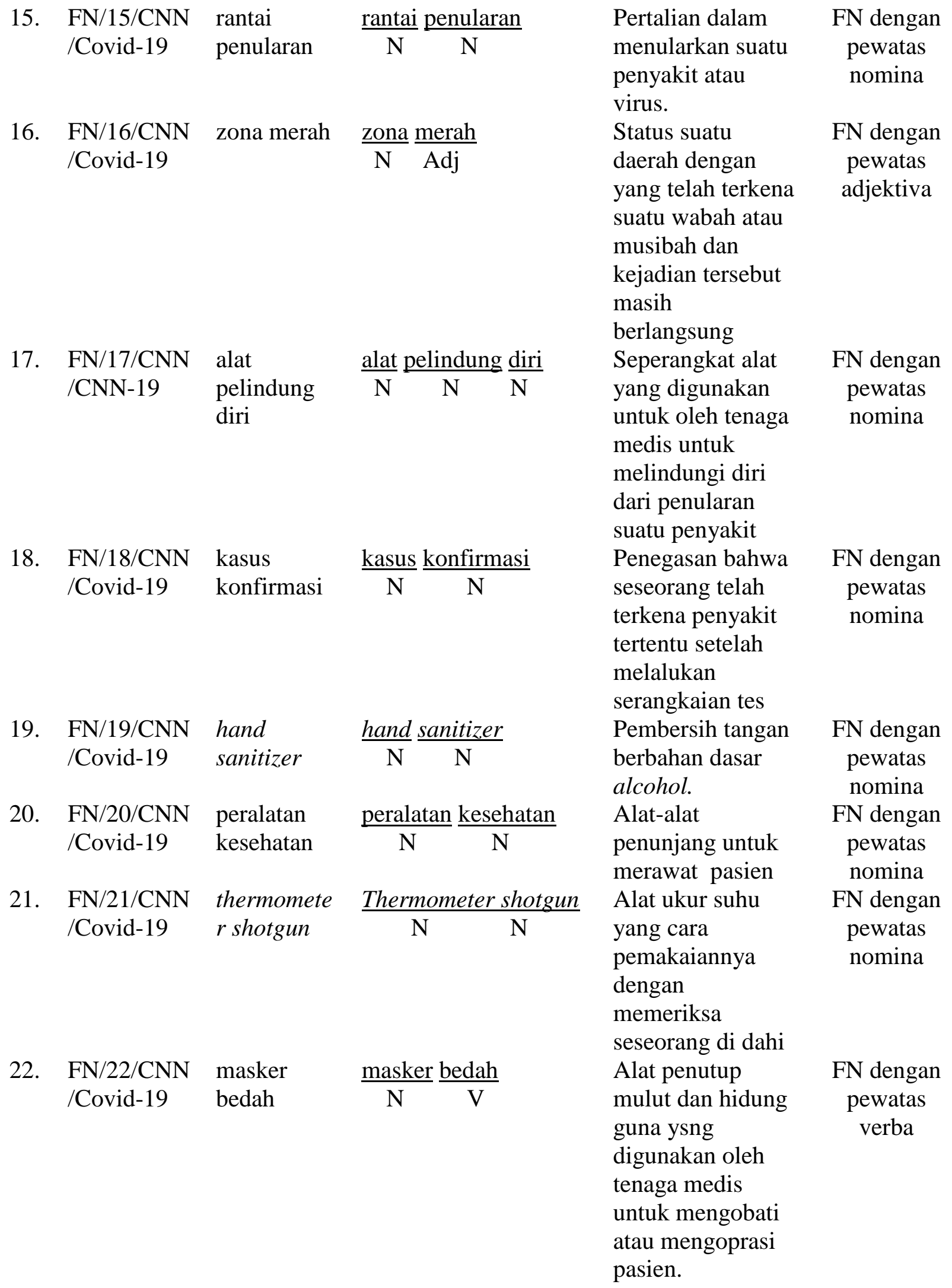




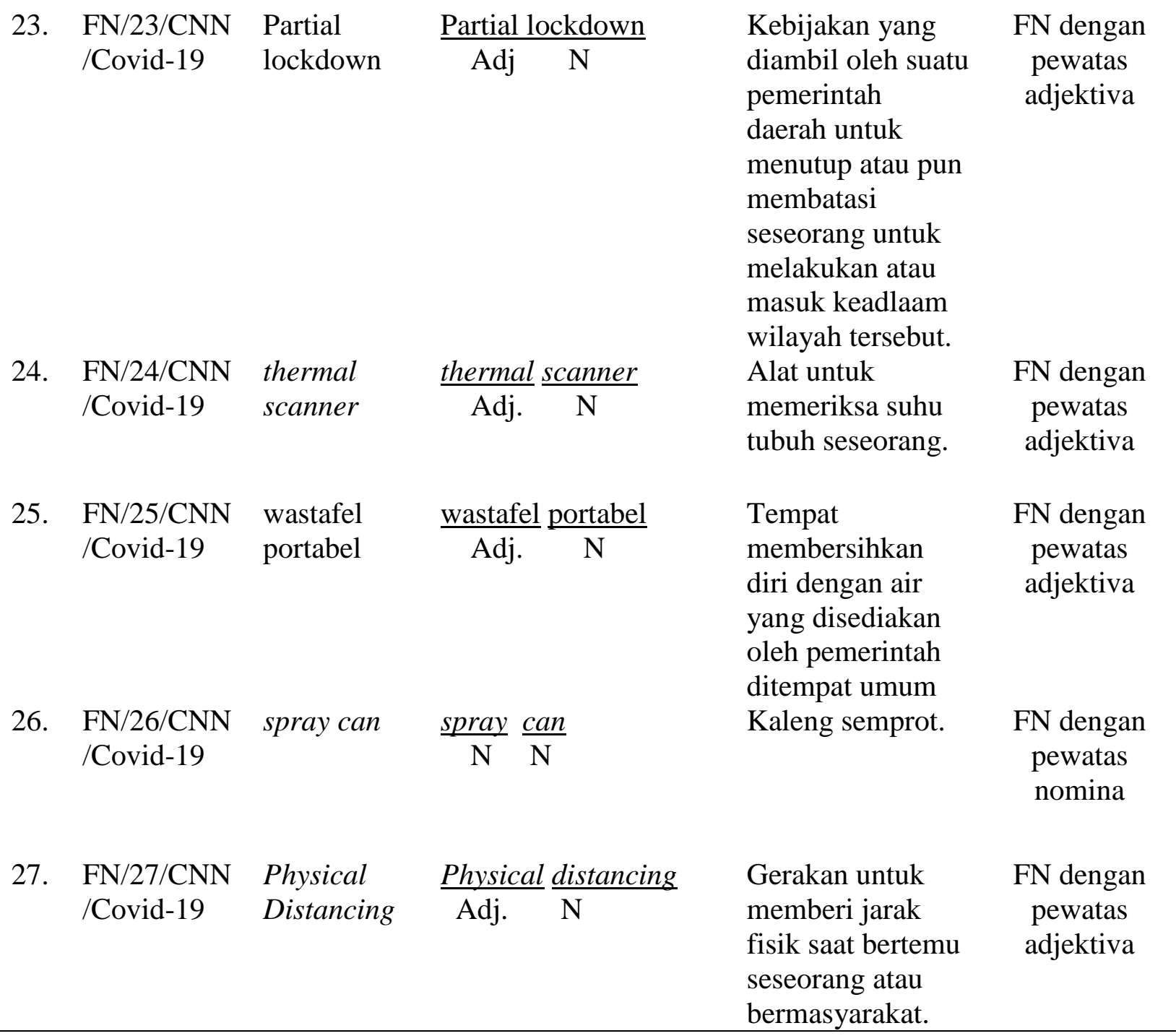

\section{Frasa Nominal dengan Pewatas Nomina}

Frasa nomina dengan pewatas nomina adalah frasa yang tediri atas nomina sebagai unsur inti dan nomina sebagai pewatasnya (atribut). Berikut adalah frasa nominal dengan pewatas nomina yang terdapat pada peristilahan COVID-19 dalam berita online CNN Indonesia:

\section{1) FN/02/CCN/Covid-19}

"Kementerian Kesehatan mencatat lima provinsi termasuk wilayah transmisi lokal penularan virus corona (covid-19)".

\section{2) FN/04/CCN/Covid-19}

"Mulai dari kluster Jakarta, imported case atau tertular saat ada di luar negeri, dan transmisi lokal". 


\section{3) FN/07/CNN/Covid-19}

"RSUP Dr Mohammad Hoesin (RSMH) Palembang bakal menambah kapasitas ruang isolasi..."

\section{4) $\mathrm{FN} / / 10 / \mathrm{CNN} /$ Covid-19}

"dan jika terdapat seseorang dari daerah terpapar dan baru pulang dari luar negeri selama rentang waktu masa inkubasi yakni 14 hari tidak diijinkan mendonor”.

\section{5) FN/12/CNN/Covid-19}

"Mahasiswa dari sejumlah prodi di Universitas Sebelas Maret (UNS) Surakarta membuat sebuah alat Disinfection Chamber (ruang disinfektan) untuk mengurangi resiko penularan virus corona..."

\section{6) $\mathrm{FN} / 14 / \mathrm{CNN} /$ Covid-19}

"Ketua Dewan Guru Besar Fakultas Kedokteran Universitas Indonesia Siti Setiati menyarankan Presiden Joko Widodo untuk melaksanakan karantina wilayah...”.

\section{7) FN/15/CNN/Covid-19}

"Langkah itu diharapkan dapat memutuskan rantai penularan baik di dalam maupun di luar wilayah"

\section{8) FN/15/CNN/Covid-19}

"Dosen Fakultas Kedokteran UI itu juga mengimbau Jokowi untuk menyediakan alat pelindung diri (APD) yang cukup untuk kebaikan para tenaga medis".

\section{9) FN/18/CNN/Covid-19}

"Ada penambahan kasus konfirmasi positif kurang lebih 103 orang sehingga jumlah totalnya 893 ".

\section{0) FN/19-22/CNN/Covid-19}

"peralatan kesehatan (alkes) untuk menangani wabah virus corona. Bantuan berbentuk Alat Pelindung Diri (APD), thermometer shot gun, hand sanitizer, dan masker bedah".

\section{1) $\mathrm{FN} / 26 / \mathrm{CNN} /$ Covid-19}

"Pagu pertama digunakan untuk membeli bahan disinfektan, masker, baju APD lengkap, thermal scanner, wastafel portable, spray can, dan bilik sterilisasi. Kemudian dana senilai Rp 10 miliar akan dicadangkan untuk kebutuhan tak terduga”. 
Berdasarkan 11 data diatas, terdapat 13 penggunaan frasa nominal dengan pewatas nomina. Terdapat frasa nominal sebagai sebutan virus yang menyebabkan seseorang terkana penyakit COVID-19 yaitu virus corona. Adapun frasa nominal yang menunjukkan status pasien yang terinfeksi penyakit di luar area dinyatakan terinfeksi (sudah terkena wabah atau penyakit tersebut) yaitu imported case, serta sebutan tempat dirawatnya pasien yang membutuhkan penanganan khusus yaitu ruang isolasi. Adapun frasa nominal yang muncul untuk menggambarkan masa seseorang dari munculnya gejala hingga sebelum tekronfirmasi terkena penyakit tersebut yaitu masa inkubasi, serta frasa nominal yang berhubungan dengan alat yang disediakan pemerintah untuk mengantisipasi terkenanya atau tersebarnya penyakit tersebut seperti Disinfection Chamber (ruang atau bilik disinfektan). Terdapat juga frasa nominal yang merupakan kebijakan yang diterapkan pemerintah untuk meminimalisir penurularan penyakit tersebut yaitu karantina wilayah, serta frasa nominal yang menunjukkan penyebab seseorang terkena penyakit atau penularan penyakit tersebut yaitu rantai penularan. Adapun frasa nominal yang berhubungan dengan peralatan yang digunakan oleh para tenaga medis dalam menangani pasien COVID-19 seperti Alat Pelindung Diri (APD), peralatan kesehatan, hand sanitizer, thermometer shot gun, dan spray can, dan juga frasa yang menunjukkan bahwa seseorang telah terkena penyakit tersebut seperti kasus konfirmasi.

\section{Frasa Nominal dengan Pewatas Adjektiva}

Frasa nominal dengan pewatas adjektiva adalah frasa yang terdiri atas nomina sebagai unsur inti dengan pewatas adjektiva. Berikut adalah frasa nominal dengan pewatas adjektiva yang terdapat pada peristilahan COVID-19 dalam berita online CNN Indonesia:

\section{1) FN/01/CNN/Covid-19}

"Kementerian Kesehatan mencatat lima provinsi termasuk wilayah transmisi lokal penularan virus corona (covid-19)".

\section{2) $\mathrm{FN} / 03 / \mathrm{CNN} /$ Covid-19}

“Dari data Rabu (25/3), jumlah pasien positif covid-19 di Indonesia mencapai 790 orang”.

\section{3) $\mathrm{FN} / 05 / \mathrm{CNN} /$ Covid-19}

"Pemerintah saat ini mulai melakukan rapid test atau tes cepat untuk mendeteksi awal seseorang terinfeksi virus atau tidak menyusul persebaran covid-19 yang semakin masif".

\section{4) $\mathrm{FN} / 06 / \mathrm{CNN} /$ Covid-19}

“Selain diprioritaskan bagi petugas medis dan orang yang pernah kontak dekat dengan pasien covid-19...”. 


\section{5) FN/08/CNN/Covid-19}

"Basis wilayah ini akan dilakukan di wilayah yang sudah ada kasus positif covid-19 dan dianggap berpotensi menular, salah satunya Jakarta Selatan”.

\section{6) $\mathrm{FN} / 09 / \mathrm{CNN} /$ Covid-19}

“...social distancing (pembatasan sosial) itu adalah menindaklanjutinya dengan mendisiplinkan warga dan warga patuh pada pemerintah".

\section{7) FN/11/CNN/Covid-19}

"Kebijakan menjaga jarak aman (safe distancing) itu dikeluarkan Singapura pada Jumat $(27 / 3) "$.

\section{8) FN/13/CNN/Covid-19}

“...dan mengingat kota Surakarta menyatakan penyakit baru itu Kejadian Luar Biasa (KLB)".

\section{9) FN/16/CNN/Covid-19}

"Karantina wilayah disarankan dilakukan selama minimal 14 hari, di provinsi-provinsi yang menjadi episentrum zona merah penyebaran COVID-19".

\section{0) $\mathrm{FN} / 23 / \mathrm{CNN} /$ Covid-19}

"Pemerintah Kota Banda Aceh akan melakukan partial lockdown atau lockdown lokal untuk menekan penyebaran virus corona, terutama di wilayah yang terdapat korban positif".

\section{1) FN/24-25/CNN/Covid-19}

"Pagu pertama digunakan untuk membeli bahan disinfektan, masker, baju APD lengkap, thermal scanner, wastafel portable, spray can, dan bilik sterilisasi. Kemudian dana senilai Rp 10 miliar akan dicadangkan untuk kebutuhan tak terduga”.

\section{2)FN/27/CNN/Covid-19}

"Dia menjelaskan bahwa kebijakan social distancing atau physical distancing (pembatasan fisik) yang dipilih pemerintah saat ini tidak akan berdampak pada penanganan penyebaran virus corona jika tak dibarengi penegakan aturan”.

Berdasarkan 12 data diatas, terdapat 13 penggunaan frasa nominal dengan pewatas Adjektiva. Terdapat frasa nominal yang menunjukkan penyebab seseorang terkena penyakit atau penularan penyakit yaitu kontak dekat dan transmisi lokal. Adapun frasa nominal yang menunjukkan status pasien yang terkena penyakit COVID-19 seperti positif COVID-19 dan kasus 
positif. Disamping itu, terdapat sebutan untuk salah satu jenis tes yang dilakukan untuk memeriksa pasien COVID-19 yaitu rapid test. Terdapat juga frasa nominal yang berhubungan dengan gerakan-gerakan yang diadakan atau diterapkan untuk mengantisipasi penyebaran ataupun memutus rantai penularan penyakit tersebut yaitu social distancing, jarak aman (safe distancing), dan Physical Distancing. Adapun frasa nominal yang menggambahrkan status suatu wilayah telah terkena bawah COVID-19 seperti Kejadian Luar biasa (KLB) dan zona merah, serta frasa nominal yang berhubungan dengan alat yang digunakan atau dibagikan seseorang untuk mengantisipasi terkenanya penyakit tersebut seperti thermal scanner dan wastafel portable. Terdapat juga frasa nominal yang merupakan kebijakan yang diterapkan pemerintah untuk meminimalisi rpenurularan penyakit tersebut yaitu partial lockdown (karantina parsial).

\section{Frasa Nominal dengan Pewatas Verba}

Frasa nominal dengan pewatas verba adalah frasa yang terdiri atas nomina sebagai unsur inti dengan pewatas verba. Berikut adalah frasa nominal dengan pewatas verba yang terdapat pada peristilahan COVID-19 dalam berita online CNN Indonesia :

\section{1) FN/22/CNN/Covid-19}

"Bantuan berbentuk Alat Pelindung Diri (APD), thermometer shot gun, hand sanitizer, dan masker bedah".

Berdasarkan pada data diatas, terdapat 1 penggunaan frasa nominal dengan pewatas verba, yaitu frasa yang menggambarkan alat penutup mulut dan hidung guna ysng digunakan oleh tenaga medis untuk mengobati atau mengoprasi pasien yang disebut dengan masker bedah.

\section{KESIMPULAN}

Berdasarkan hasil penelitian dan pembahasan, dapat disimpulkan bahwa terdapat 3 bentuk frasa nominal yang digunakan dalam peristilahan COVID-19 pada berita online CNN Indonesia, yaitu frasa nominal dengan pewatas nomina, pewatas adjektiva, dan pewatas verba. Terdapat 11 data dengan 13 penggunaan frasa nominal dengan pewatas nomina, 12 data dengan 13 penggunaan frasa nominal dengan pewatas adjektiva, serta 1 data dengan penggunaan frasa nominal dengan pewatas verba. Sehingga, Terdapat persamaan jumlah data antara penggunaan frasa nominal dengan pewatas nomina dan pewatas adjektiva, yaitu 13 data. Adapun jumlah frasa nominal yang muncul dalam 8 artikel peristilahan COVID-19 tersebut adalah 27 frasa nominal.

Dari 27 frasa nominal tersebut, terdapat frasa nominal yang berhubungan dengan alat kesehatan serta alat- alat yang digunakan untuk memutus penyebaran ataupun rantai penularan 
penyakit COVID-19 . Disamping itu, terdapat pula frasa nominal yang berhubungan dengan gerakan-gerakan sosial yang diterapkan oleh masyarakat, kebijakan daerah yang diterapkan oleh masing-masing pemerintah daerah, status- status pasien yang terkena penyakit COVID-19, status gawat darurat pada suatu daerah, serta tempat yang menjadi tempat dirawatnya pasien yang membutuhkan penanganan khusus setelah terkena penyakit COVID-19.

Penting bagi masyarakat untuk memahami istilah-istilah yang muncul terkait dengan COVID-19, tak terkecuali frasa nominal yang terdapat dalam artikel pemberitaan COVID-19. Sehingga, masyarakat mampu memahami bahwa kebijakan-kebijakan yang dibuat oleh pemerintah saat ini harus dipatuhi dan dilaksanakan dengan baik sebagai bentuk partisipasi nyata dalam mencapai tujuan bersama, yaitu memutus penularan ataupun penyebaran penyakit COVID19 yang telah memakan banyak korban dan nyawa. Dengan adanya koordinasi yang baik antara pemerintah dan masyarakat, maka langkah -langkah yang telah dilaksanakan serta kebijakankebijakan yang telah dibuat dan diterapkan oleh pemerintah dapat berhasil dan menjadi upaya yang berhasil dalam meredam penyebaran COVID-19, mengingat bahwa pencegahan tidak hanya dapat dilakukan oleh pemerintah saja, namun juga seluruh lapisan masyarakat. Terlebih lagi karena penularan masih terjadi di antara warga, sehingga penting bagi masyarakat untuk selalu mengedukasi diri dan selalu waspada untuk menjaga keselamatan diri serta menyadari bahwa pandemi yang terjadi secara global ini merupakan hal yang harus disikapi secara serius.

Dengan adanya penelitian ini, peneliti berharap bahwa penelitian ini dapat menjadi referensi penelitian bidang sintaksis bagi peneliti yang akan datang, serta dapat menjadi salah satu bentuk kampanye dalam mencegah COVID-19 yang dilakukan dengan mengkaji frasa-frasa nominal yang muncul dalam peristilahan COVID-19 sebagai bentuk edukasi kepada masyarakat melalui bidang kebahasaan.

\section{DAFTAR PUSTAKA}

Afandi, I. (2018). Analisis Penggunaan Frasa Nomina dari Segi Sintaksis dalam Teks Akademik (Tesis). Jurnal Reserch Gate.

Arifin, Z dan Junaiyah. (2009). Sintaksis. Jakarta: PT Grasindo.

Chaer, A. (2009). Sintaksis Bahasa Indonesia (Pendekatan Proses). Jakarta Rineka Cipta.

Dongalemba, R. M. (2018). Fungsi Eksternal dan Kategori Frasa Nomina Bahasa Melayu Menado. Jurnal Kajian Linguistik. Nomor 1, hlm 38-51. 
Faisal. (2009). Bahan Ajar Cetak Kajian Bahasa Indonesia SD 3 SKS. Jakarta: Direktorat Jenderal Pendidikan Tinggi Departemen Pendidikan Nasional.

Jerniati, I. (2013). Posisi Pewatas Dalam Frasa Nomina Bahasa Mandar: Suatu Pendekatan Transformasi Generatif. Jurnal Sawerigading. Volume (19), Nomor 1, hlm 7-15.

Manaf, N. A. (2009). Sintaksis: Teori dan Terapannya dalam Bahasa Indonesia. Padang: Sukabina Press.

Permana, D. (2010). Frasa Nominal dalam Bahasa Banjar Samarinda. Jurnal EKSIS. Volume (6), Nomor 1, 1375-1379.

Rahman, M. (2015). Penggunaan Frasa Bahasa Indonesia dalam Karangan Siswa Kelas VII MTSn Rengel Tahun Pelajaran 2014/2015. Jurnal BASTRA. Volume (2), Nomor 2, hlm 127-138.

Salwen, M. B., Garrison, B., Driscoll, P. D. (2005). Online news and the public. London: Routledge.

Santosa, R. (2014). Metode Penelitian Kualitatif Kebahasaan. Surakarta: Universitas Sebelas Maret Press.

Sugiyono. (2009). Metode Penelitian Kualitatif Kuantitatif dan R\&D. Bandung: Alfabeta.

Sumadiria, H. (2005). Jurnalistik Indonesia, Menulis Berita dan Feature, Panduan Praktis Jurnalis Profesional. Bandung: Remaja Rosdakarya.

Tarmini, W. (2012). Buku Ajar Sintaksis Bahasa Indonesia. Bandar Lampung: Universitas Lampung.

Tim Penyusun. Kamus Besar Bahasa Indonesia (KBBI) edisi V. Melalui Daring (http://kbbi.web.id/, diakses pada 9 April 2020).

Widjono. (2008). Bahasa Indonesia. Jakarta: Grasindo.

\section{Sumber Rujukan Internet}

Agt, \& Bir. (2020). Investor China Kirim 40 Ton Alat Kesehatan untuk Atasi Corona. https://www.cnnindonesia.com/ekonomi/20200327181218-92-487666/investor-china-kirim-40ton-alat-kesehatan-untuk-atasi-corona

Ang, \& Dea. (2020). Singapura Denda Warga yang Duduk Dekatan hingga Rploo Juta. https://www.cnnindonesia.com/internasional/20200327131053-106-487470/singapura-dendawarga-yang-duduk-dekatan-hingga-rp100-juta

Dhf, \& Arh. (2020). Viral, Guru Besar FK UI Minta Jokowi Terapkan Local Lockdown. https://www.cnnindonesia.com/nasional/20200327124707-20-487457/viral-guru-besar-fk-uiminta-jokowi-terapkan-local-lockdown

Dmr, \& Antara/kid. (2020). Jawa Tengah Punya Laboratorium Pemeriksa Covid-19. https://www.cnnindonesia.com/nasional/20200326204638-20-487316/jawa-tengah-punyalaboratorium-pemeriksa-covid-19 
Eks, \& Eks. (2020). Cegah Corona, Mahasiswa UNS Buat Ruang Penyemprot Disinfektan. https://www.cnnindonesia.com/teknologi/20200327095117-199-487395/cegah-coronamahasiswa-uns-buat-ruang-penyemprot-disinfektan

Idz, \& Haz. (2020). PDP Corona Naik, RSMH Palembang Tambah Kapasitas Isolasi. https://www.cnnindonesia.com/nasional/20200327001127-20-487332/pdp-corona-naik-rsmhpalembang-tambah-kapasitas-isolasi

Khr, \& Kid. (2020). Stok Darah Berkurang saat Corona, PMI Jemput Bola Pendonor. https://www.cnnindonesia.com/nasional/20200326202907-20-487306/stok-darah-berkurangsaat-corona-pmi-jemput-bola-pendonor

Psp, \& Sur. (2020). Daftar Wilayah Transmisi Lokal Virus Corona di Indonesia. https:/www.cnnindonesia.com/nasional/20200326070039-20-486907/daftar-wilayah-transmisilokal-virus-corona-di-indonesia 